\title{
Characterization of Cordierite Synthesized from Egyptian Kaolin and Talc
}

\author{
M.M. Selima*, S.A. Hassan ${ }^{\mathrm{b}}$, M.R.A. Rezk ${ }^{\mathrm{c}}$ and N.M. \\ Deraz $^{\text {a,d }}$ \\ ${ }^{a}$ Department of Physical Chemistry, National Research Center, \\ ${ }^{b}$ Department of Chemistry, Faculty of Science, Ain Shams \\ University, ${ }^{c}$ Ministry of Scientific Research and ${ }^{d}$ Department of \\ Chemistry, College of Science, King Saud University, Kingdom \\ of Saudi Arabia.
}

\begin{abstract}
7 HE SYNTHESIS of cordierite from Egyptian Kaolin, Talc and $\mathrm{Al}(\mathrm{OH})_{3}$ by solid state reaction at different temperature 1250 $1350{ }^{\circ} \mathrm{C}$ has been studied. The samples of the synthesized cordierite obtained from different compositions of raw materials were characterized by X-Ray Diffraction (XRD) and Scanning Electron Microscope (SEM). The XRD analysis showed $\alpha$-cordierite as a major phase for samples calcined at $1350{ }^{\circ} \mathrm{C}$ for $1 \mathrm{hr}$. The morphology of the surface of prepared cordierite appeared to be homogenous, smooth and non pours. Density and porosity of the prepared cordierite were also determined.
\end{abstract}

Keywords: Solid state reaction, Cordierite, Talc and Kaolin.

Cordierite ceramics have been extensively studied in the last decades, due to their excellent properties, low thermal expansion coefficient, excellent thermal shock resistance, low dielectric constant, high volume resistivity, high chemical durability, high refractoriness and high mechanical strength. Therefore, they are widely used as honeycomb-shaped catalyst carriers in automobile exhaust systems, as substrate material for integrated circuit boards and as refractory materials ${ }^{(1-6)}$.

Occurring of natural cordierite is very rare in nature ${ }^{(7)}$. Karkhanavala and Hummel investigated three polymorphs of cordierite as far back as 1953, a stable low-temperature $(\beta)$ form, a metastable low-temperature $(\mu)$ form, and a stable high-temperature $(\alpha)$ form. The high-temperature form can be obtained by solidstate reaction of batch material at $1300^{\circ} \mathrm{C}$ to $1460^{\circ} \mathrm{C}$, or by crystallization of the glass between $1050^{\circ} \mathrm{C}$ and $1460^{\circ} \mathrm{C}$. The metastable low temperature form is not easily developed and requires many hours of crystallization of finely powdered glass at temperatures around $800^{\circ} \mathrm{C}$ and $900^{\circ} \mathrm{C}$. The stable low-temperature form

$\overline{\text { *Corresponding author: E-mail mmaselim@yahoo.com }}$ 
is developed only by hydrothermal treatment of glass, the $\mu$ form, or the $\alpha$ form at temperatures below $830^{\circ} \mathrm{C}^{(1)}$.

The most common method to synthesize cordierite is the high temperature reaction in the solid state, although chemical methods, such as co-precipitation reactions, solution combustion or sol- gel technology have been proposed in order to decrease the synthesis temperature and to improve physical properties. Among these methods, sintering of oxide powders through solid state reactions is the most popular.

Some of the starting raw materials reported in literature include (i) a mixture of magnesium compounds and kaolinite ${ }^{(1)}$, (ii)alkaline-earth-aluminosilicate glass, kaolin, alumina and magnesite ${ }^{(2)}$, (iii) talc, calcined alumina and fly ash ${ }^{(3)}$, (iv) kaolin, talc, silica and alumina ${ }^{(4)}$, (v) talc, kaolinitic clay and gibbsite ${ }^{(5)}$, (vi) kaolin, talc and magnesium oxide ${ }^{(6)}$, (vii) talc, kaolin, silica, sepiolite and feldspar $^{(8)}$, and (viii) kaolin and talc ${ }^{(9)}$.

In the present work, solid state methods was employed for the preparation of cordierite, starting with different compositions of kaolin, Talc and alumina.

\section{Experimental}

\section{Materials}

The raw materials used in this work were Kaolin (Egypt), talc (Egypt) with the composition shown in Table 1 , determined by X-ray fluorescence and aluminum hydroxide (Merck).

TABLE 1. The chemical compositions of Kaolin and talc (wt.\%), determined by $\mathrm{X}$-ray fluorescence.

Materials $\mathrm{SiO}_{2} \mathrm{TiO}_{2} \mathrm{Al}_{2} \mathrm{O}_{3} \mathrm{Fe}_{2} \mathrm{O}_{3}$ tot $\mathrm{MnO} \mathrm{MgO} \mathrm{CaO} \mathrm{Na}_{2} \mathrm{O} \quad \mathrm{K}_{2} \mathrm{O} \quad \mathrm{NiO} \mathrm{Cr}_{2} \mathrm{O}_{4} \mathrm{SO}_{3}$ L.O.I

\begin{tabular}{lllllllllllllll}
\hline Kaolin & 50.81 & 2.46 & 31.69 & 2.13 & 0.01 & 0.41 & 0.74 & 0.05 & 0.08 & - & - & 0.2 & 11 \\
Talc & 58.65 & 0.02 & 1.14 & 5.52 & 0.04 & 26.63 & 1.26 & - & - & 0.26 & 0.16 & 0.08 & 6.1 \\
\hline
\end{tabular}

The most common mineral in the production of cordierite $e^{(10-12)}$ is kaolin $\left(\mathrm{Al}_{2} \mathrm{O}_{3} .2 \mathrm{SiO}_{2} .2 \mathrm{H}_{2} \mathrm{O}\right)$ that used as a source of $\mathrm{SiO}_{2}$ and $\mathrm{Al}_{2} \mathrm{O}_{3}$, also increases the plastic behavior of the batch. Talc $\left(3 \mathrm{MgO} \cdot 4 \mathrm{SiO}_{2} \cdot \mathrm{H}_{2} \mathrm{O}\right)$ has also been used as raw material for cordierite synthesis in many studies, it used as the source of $\mathrm{MgO}$ and $\mathrm{SiO}_{2}{ }^{(11-13)}$. The Raw materials were chosen as components in this study because of its low impurity content and they are local product.

\section{Preparation of cordierite}

In the literature, based on the $\mathrm{SiO}_{2}-\mathrm{MgO}-\mathrm{Al}_{2} \mathrm{O}_{3}$ diagram ${ }^{(14)}$ some researchers have employed a 1:1:2 mole ratio ${ }^{(11,12)}$ while some others have used a 2:2:5 mole

Egypt. J. Chem. 53, No. 4 (2010) 
ratio $\mathrm{MgO}-\mathrm{Al}_{2} \mathrm{O}_{3}-\mathrm{SiO}_{2}$ for cordierite ${ }^{(10,15)}$. In this work, the raw materials were mixed in proper amounts to obtain 2:2:5 stoichiometric cordierite mixtures.

Five batch compositions of kaolin and talc were mixed with different amount of aluminum hydroxide to attain 2:2:5 mole ratio of $\mathrm{MgO}-\mathrm{Al}_{2} \mathrm{O}_{3}-\mathrm{SiO}_{2}$ for cordierite composition as listed in Table 2. Then, the raw materials were ground in a ball mill to obtain homogenized mixtures.

TABLE 2. Batches composition (wt. \%).

\begin{tabular}{cccc}
\hline Sample code & Kaolin & Talc & Al $(\mathbf{O H})_{\mathbf{3}}$ \\
\hline C1 & 37.19 & 29.75 & 33.06 \\
C2 & 36.66 & 29.33 & 34.01 \\
C3 & 36.15 & 28.91 & 34.94 \\
C4 & 35.65 & 28.52 & 35.83 \\
C5 & 35.17 & 28.13 & 36.70 \\
\hline
\end{tabular}

The powders were pressed uniaxially in a universal hydraulic press (MEGA KSC-10A) at 120 MPa pressure in a stainless steel die. The prepared specimens were heated at different temperatures of 1250,1300 and $1350^{\circ} \mathrm{C}$ with soaking time of $1 \mathrm{hr}$ with constant heating rate of $10^{\circ} \mathrm{C} / \mathrm{min}$. The kiln was allowed to cool by itself in air.

\section{Techniques}

An X-ray diffraction investigation of samples preheated in air at 1250, 1300 and $1350{ }^{\circ} \mathrm{C}$ was conducted using Bruker D8 diffractometer with $\mathrm{Cu}-\mathrm{k} \alpha$ radiation $(\lambda=1.54)$ at $40 \mathrm{kV}$ and $40 \mathrm{~mA}$. Scanning electron microscopy (SEM) was taken on (Philips XL30); the samples were first sputtered with a thin layer of gold to avoid charging.

\section{Results and Discussion}

\section{$X$-ray diffraction analyses}

The phases formed for different batch compositions C1- C5 after sintering at different temperatures ranging from $1250{ }^{\circ} \mathrm{C}$ to $1350{ }^{\circ} \mathrm{C}$ were identified by XRD and are shown in Fig. 1-5, where the signals are associated to the cordierite substrate identified with $\alpha$ symbol. Diffractograms show the presence of the phases mullite and cristobalite for $\mathrm{C} 1$ composition at $1250^{\circ} \mathrm{C}$ (Fig. 1). When the temperature is raised upto $1300^{\circ} \mathrm{C}$ the cordierite phase appeared but the intensity of the lines is still low due to low crystallinity indicating that, the solid state reaction is started. At $1350^{\circ} \mathrm{C}$ a considerable increase in crystallinity is observed, with a large number of patterns corresponding to cordierite. 


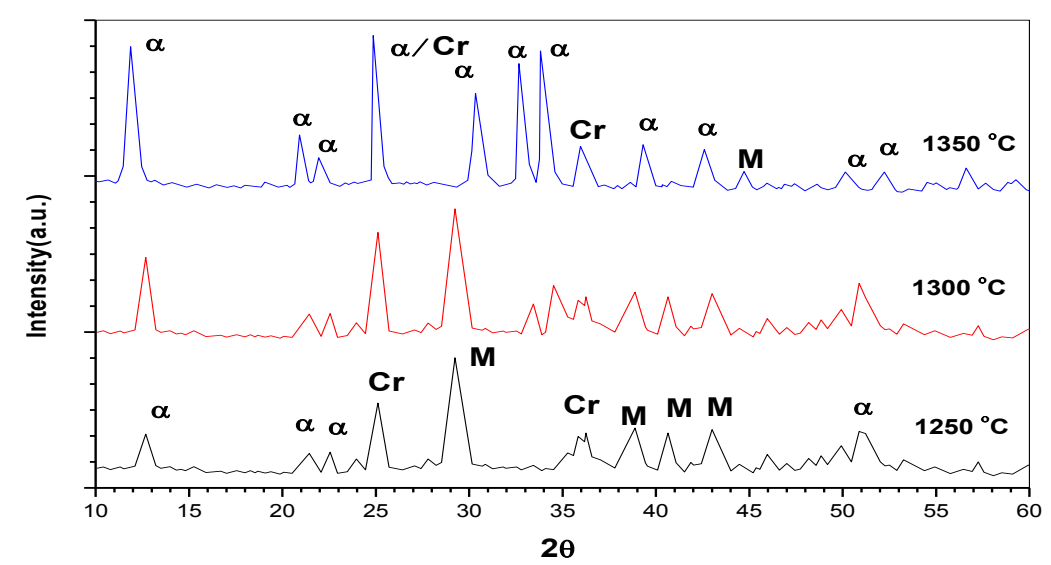

Fig. 1. XRD pattern of $\mathrm{C} 1$ composition after calcinations between $1250^{\circ} \mathrm{C}$ and $1_{350}^{\circ} \mathrm{C}$ for $1 \mathrm{hr}(\alpha=$ Cordierite, $\mathrm{Cr}=$ Cristobalite and $\mathrm{M}=$ Mullite $)$.

Diffractograms of C2 composition (Fig. 2) at $1250^{\circ} \mathrm{C}$ show the appearance of cristobalite and mullite patterns. The increase of temperature up to $1300^{\circ} \mathrm{C}$ the pattern of cordierite appeared but with low intensity. At $1350^{\circ} \mathrm{C}$ pattern of cordierite was detected but still with low intensity and the phases of cristobalite and mullite are still existed. X-ray diffraction patterns of $\mathrm{C} 3$ composition (Fig.3), show that sample preheated at $1250{ }^{\circ} \mathrm{C}$ gives cordierite with patterns of low intensities. Further increase of temperature upto $1350^{\circ} \mathrm{C}$ a large number of patterns related to cordierite was detected, while the lines corresponding to quartz, cristobalite and mullite greatly diminished. From X-ray diffractograms of C4 and C5 compositions (Fig. 4, 5), it can be seen that cristobalite, mullite and cordierite phases appeared at all calcination temperature.

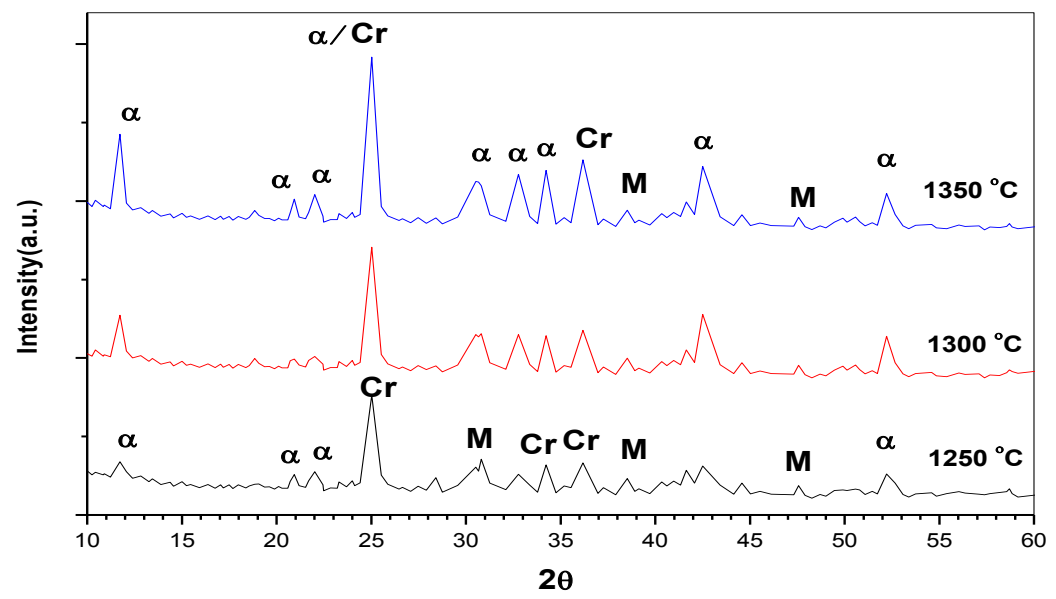

Fig. 2. XRD pattern of $\mathrm{C} 2$ composition after calcinations between $1250^{\circ} \mathrm{C}$ and $1_{350}^{\circ} \mathrm{C}$ for $1 \mathrm{hr}(\alpha=$ Cordierite, $\mathrm{Cr}=$ Cristobalite and $\mathrm{M}=$ Mullite $)$.

Egypt. J. Chem. 53, No. 4 (2010) 


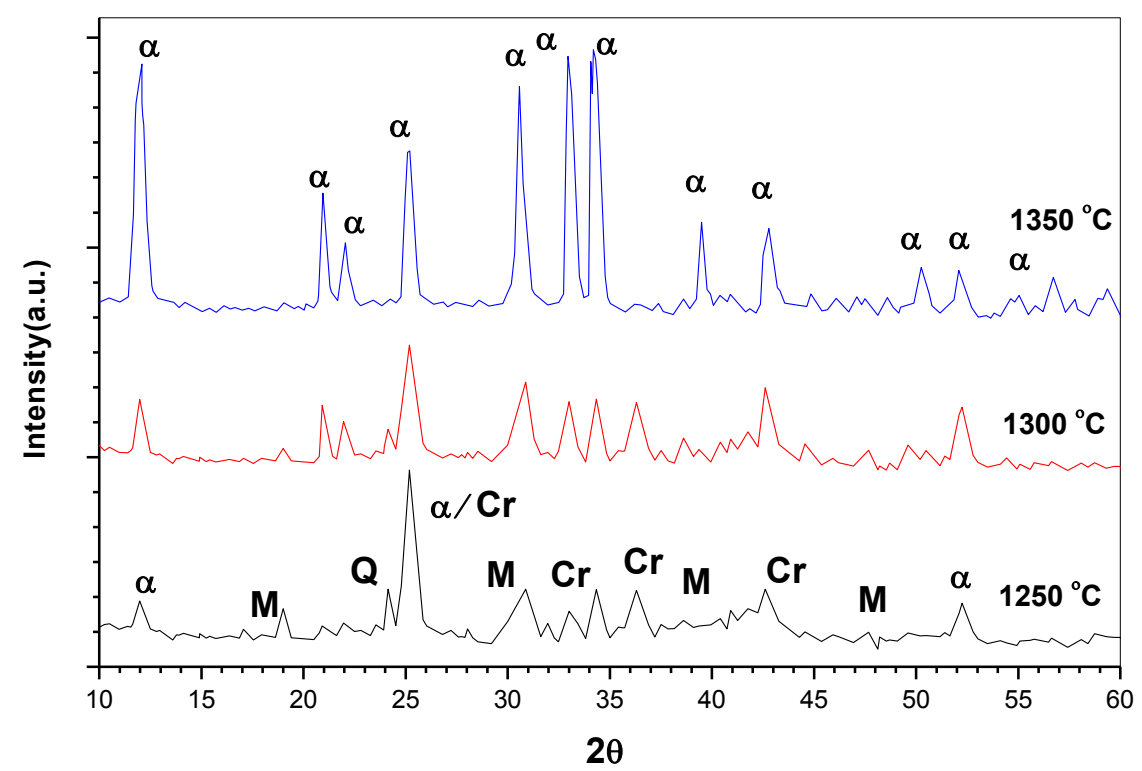

Fig. 3. XRD pattern of $\mathrm{C} 3$ composition after calcinations between $1250^{\circ} \mathrm{C}$ and $1350^{\circ} \mathrm{C}$ for $1 \mathrm{hr}(\alpha=$ Cordierite, $\mathrm{Q}=$ Quartz, $\mathrm{Cr}=$ Cristobalite and $\mathrm{M}=$ Mullite).

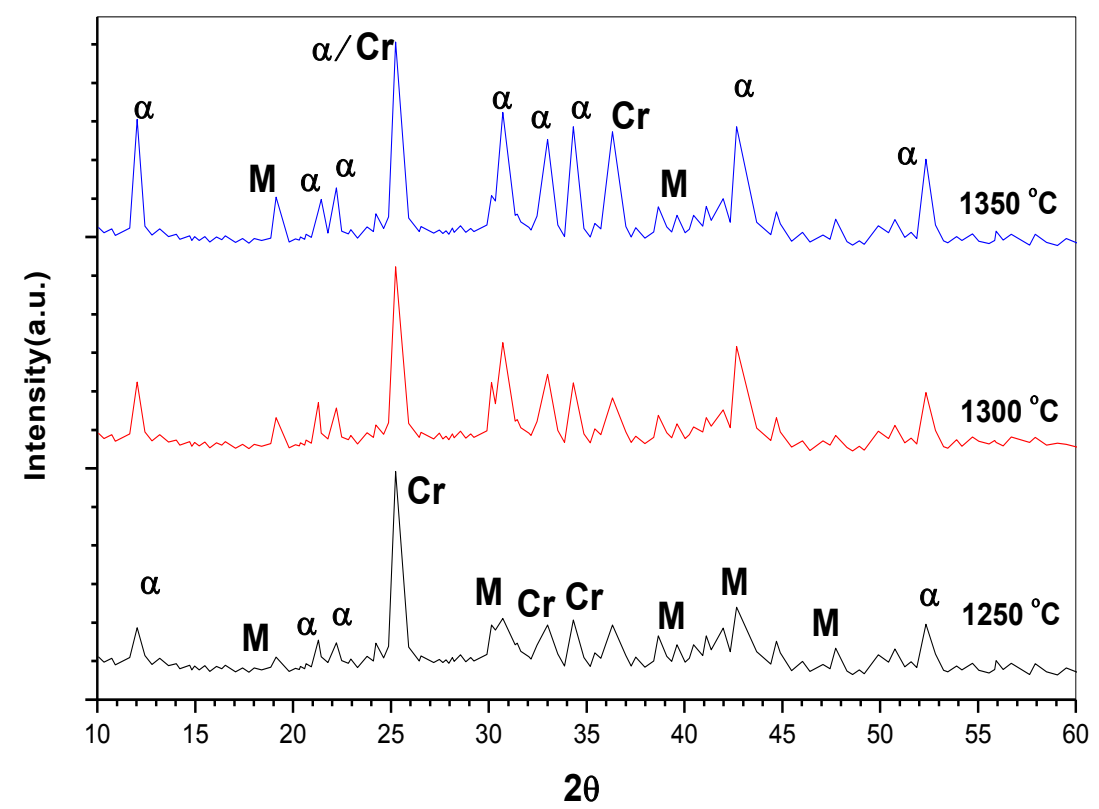

Fig. 4. XRD pattern of $\mathrm{C} 4$ composition after calcinations between $1250^{\circ} \mathrm{C}$ and $1350^{\circ} \mathrm{C}$ for $1 \mathrm{hr}(\alpha=$ Cordierite, $\mathrm{Cr}=$ Cristobalite and $\mathrm{M}=$ Mullite). 


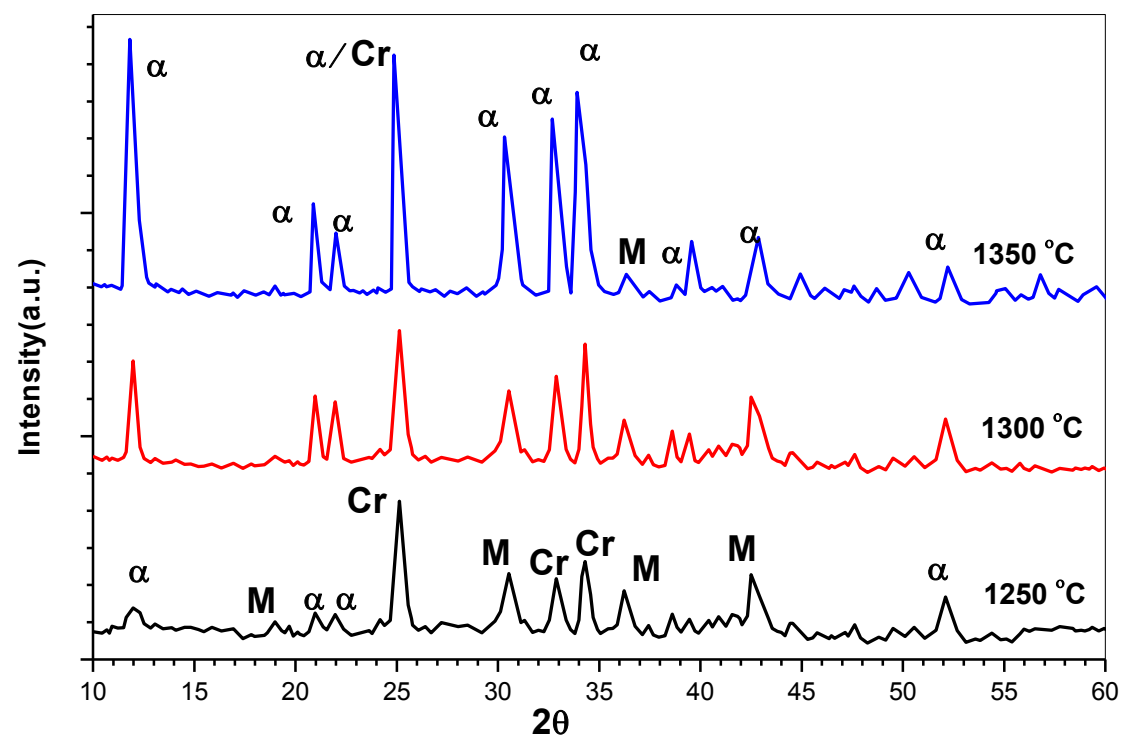

Fig. 5. XRD pattern of $\mathrm{C} 5$ composition after calcinations between $1250^{\circ} \mathrm{C}$ and $1350^{\circ} \mathrm{C}$ for $1 \mathrm{hr}(\alpha=$ Cordierite, $\mathrm{Q}=$ Quartz, $\mathrm{Cr}=$ Cristobalite and $\mathrm{M}=$ Mullite).

Based on these results, it can be found that, at $1250^{\circ} \mathrm{C}$ and $1300{ }^{\circ} \mathrm{C}$ all compositions produce more than one phase and at $1350{ }^{\circ} \mathrm{C}$ the only composition produces pure cordierite was $\mathrm{C} 3$, which exhibit well crystalline phase and has an excellent degree of crystallinity. Table 3 summarized the result of $\mathrm{X}$ - ray patterns of five compositions.

TABLE 3. Summarized results of $x$ - ray analysis of five compositions preheated at different temperatures.

\begin{tabular}{|c|c|c|c|}
\hline \multirow{2}{*}{ Sample Code } & \multicolumn{3}{|c|}{ Phase Formed* } \\
\hline & $1250^{\circ} \mathrm{C}$ & $1300^{\circ} \mathrm{C}$ & $1350^{\circ} \mathrm{C}$ \\
\hline $\mathrm{C1}$ & $\alpha, \mathrm{Cr}, \mathrm{M}$ & $\alpha, \mathrm{Cr}, \mathrm{M}$ & $\alpha, \mathrm{Cr}, \mathrm{M}$ \\
\hline $\mathrm{C2}$ & $\alpha, \mathrm{Cr}, \mathrm{M}, \mathrm{Q}$ & $\alpha, \mathrm{Cr}, \mathrm{M}$ & $\alpha, \mathrm{Cr}, \mathrm{M}$ \\
\hline $\mathrm{C3}$ & $\alpha, \mathrm{Cr}, \mathrm{M}, \mathrm{Q}$ & $\alpha, \mathrm{Cr}, \mathrm{M}, \mathrm{Q}$ & $\alpha$ \\
\hline $\mathrm{C4}$ & $\alpha, \mathrm{Cr}, \mathrm{M}, \mathrm{Q}$ & $\alpha, \mathrm{Cr}, \mathrm{M}$ & $\alpha, \mathrm{Cr}, \mathrm{M}$ \\
\hline C5 & $\alpha, \mathrm{Cr}, \mathrm{M}, \mathrm{Q}$ & $\alpha, \mathrm{Cr}, \mathrm{M}$ & $\alpha, \mathrm{Cr}, \mathrm{M}$ \\
\hline
\end{tabular}

$* \alpha=$ Cordierite, $\mathrm{Q}=$ Quartz, $\mathrm{Cr}=$ Cristobalite and $\mathrm{M}=$ Mullite.

Egypt. J. Chem. 53, No. 4 (2010) 


\section{Density and porosity evaluation}

Cordierite sample C3 was subjected to physical property evaluation as ASTM standards ${ }^{(16)}$. The density and porosity of the synthesized cordierite mixtures were determined using Archimedes' technique. It gives low apparent porosity values $(10.25 \%)$, due to that the closed porosity increases with sintering temperature, because some closed pores formed in the liquid phase of low viscosity at higher temperatures. The bulk density was $\left(2.2 \mathrm{~g} / \mathrm{cm}^{3}\right)$

\section{Scanning electron microscope (SEM)}

In order to investigate the morphology of cordierite, SEM analysis was performed. The SEM of samples shown in Fig. 6 corresponds to C3 sample. The surface of cordierite appeared to be smooth, homogenous and non porous due to calcination at high temperature $1350^{\circ} \mathrm{C}$, which matches with the porosity measurements using Archimedes' technique.

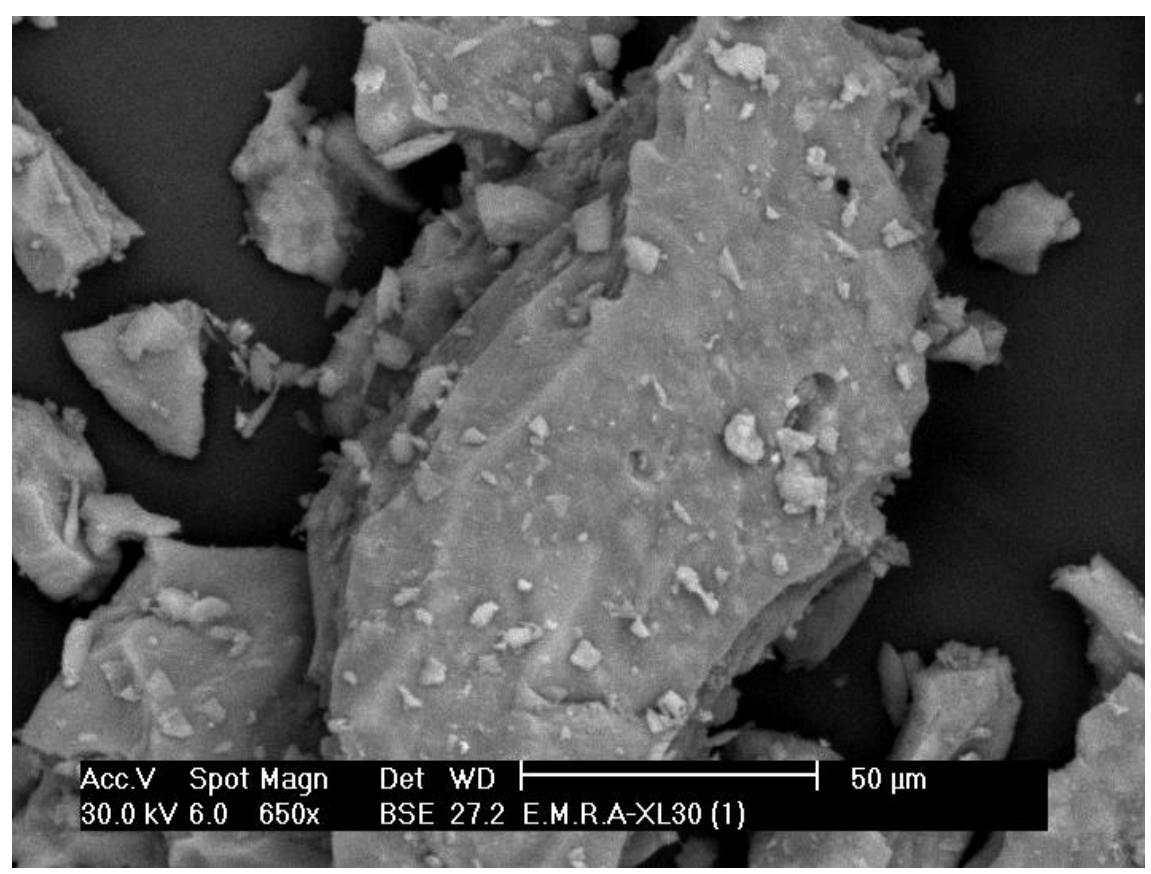

Fig. 6-a. SEM images of cordierite ceramics (Sample C3) sintered at $1350^{\circ} \mathrm{C}$ for $1 \mathrm{hr}$ soaking time at magnification $650 x$. 


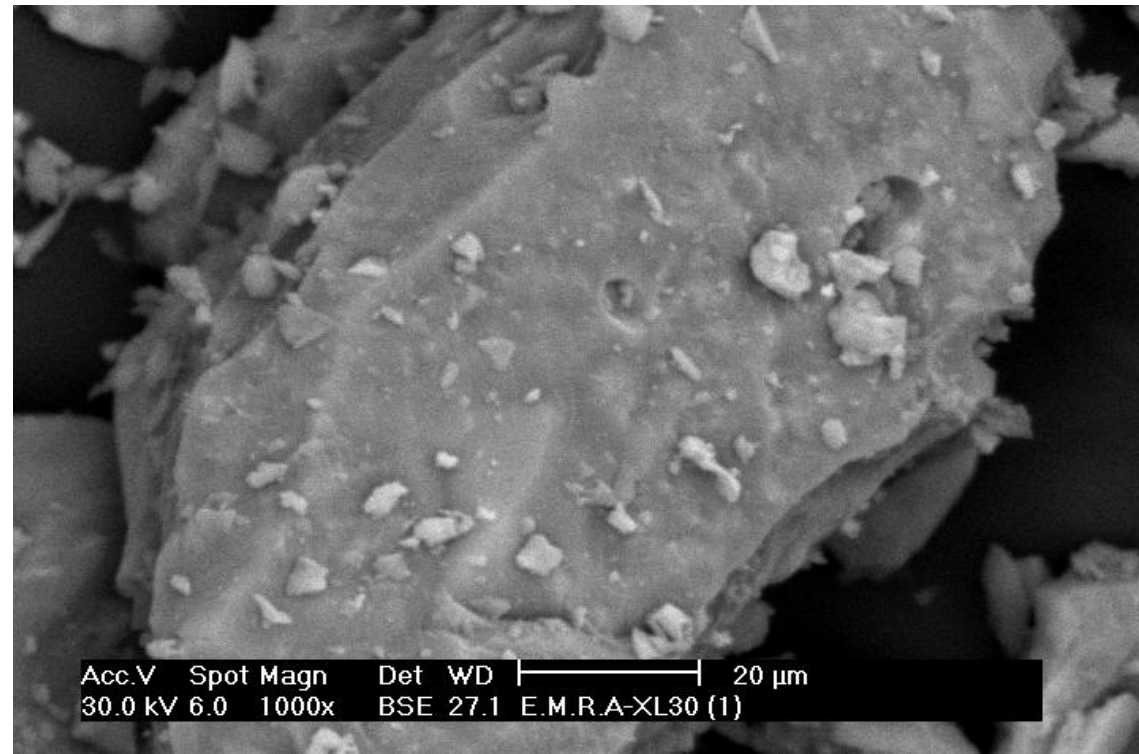

Fig. 6-b. SEM images of cordierite ceramics (Sample C3) sintered at $1350^{\circ} \mathrm{C}$ for $1 \mathrm{hr}$ soaking time at magnification 1000x.

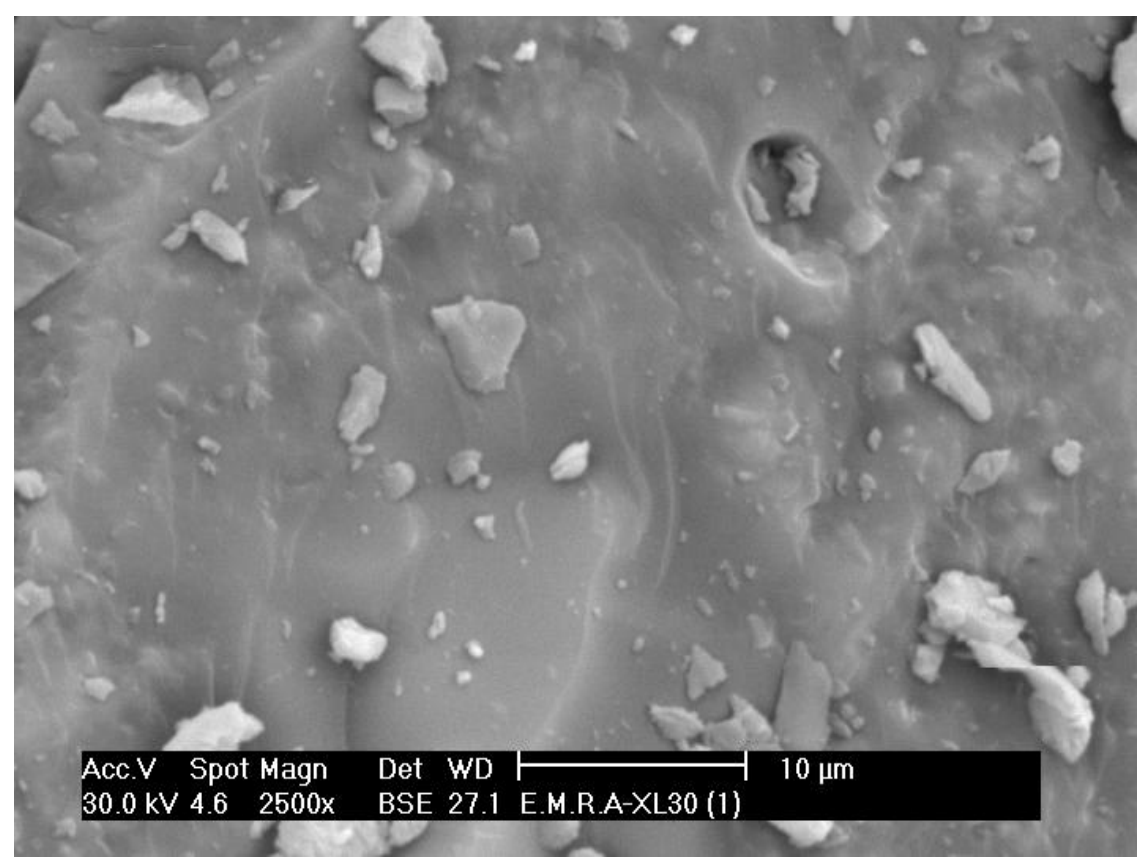

Fig. 6-c. SEM images of cordierite ceramics (Sample C3) sintered at $1350^{\circ} \mathrm{C}$ for $1 \mathrm{hr}$ soaking time at magnification $2500 x$.

Egypt. J. Chem. 53, No. 4 (2010) 


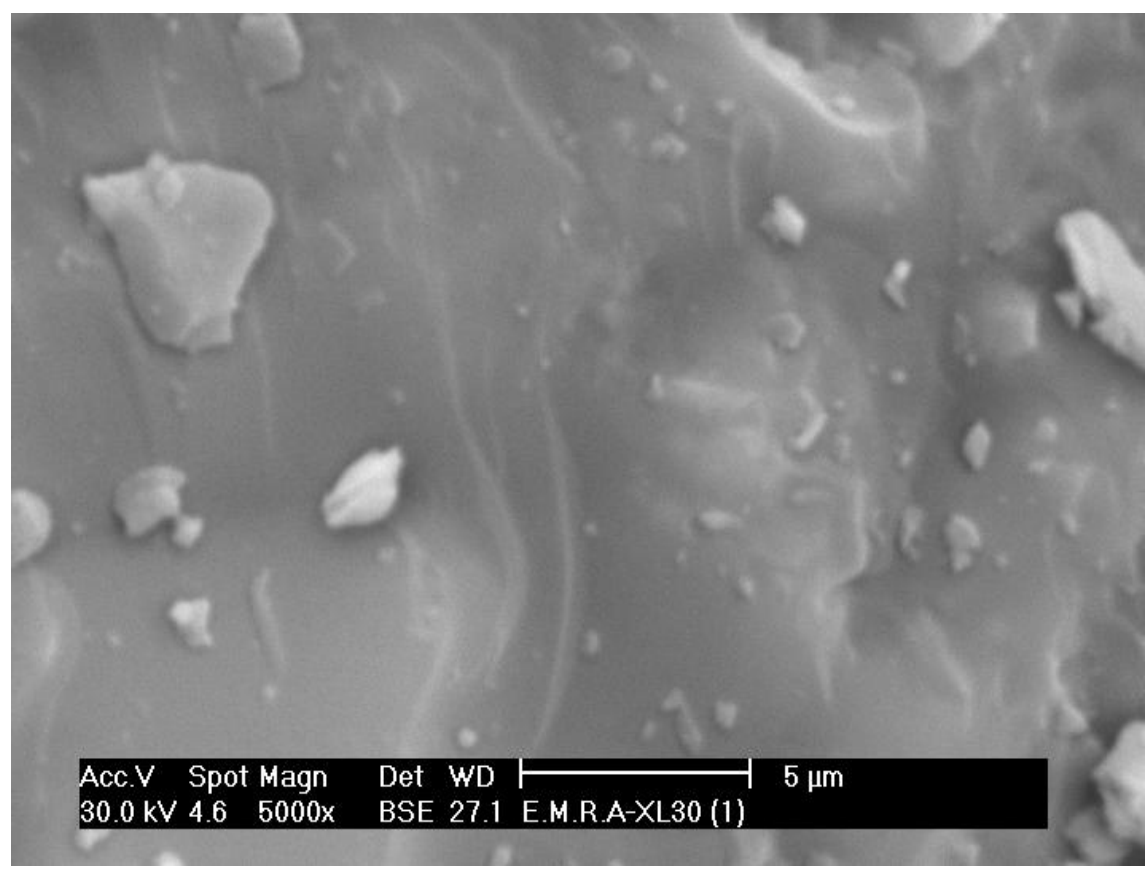

Fig. 6-d. SEM images of cordierite ceramics (Sample C3) sintered at $1350^{\circ} \mathrm{C}$ for $1 \mathrm{hr}$ soaking time at magnification $5000 \mathrm{x}$.

\section{Conclusion}

In this work, cordierite ceramic was prepared by solid state reaction between Egyptian kaolin, talc and aluminum hydroxide, where different batch composition examined. X-ray diffraction method proved pure cordierite phase in sample $\mathrm{C} 3$ preheated at $1350^{\circ} \mathrm{C}$ for $1 \mathrm{hr}$ soaking time and the surface was homogenous and non porous as shown by SEM.

\section{References}

1. Kobayashi, Y., Sumi, K. and Kato, E., Preparation of dense cordierite ceramics from magnesium compounds and kaolinite without additives, Ceram. Int. 26, 739743(2000).

2. Tulyaganov, D.U., Tukhtaev, M.E. Escalante, J.I., Ribeiro, M.J. and Labrincha, J.A., Processing of cordierite based ceramics from alkaline-earth-aluminosilicate glass, kaolin, alumina and magnesite, J. Eur. Ceram. Soc. 22, 1775-1782 (2002).

3. Kumar, S., Singh, K.K. and Ramachadrarao, P., Synthesis of cordierite from fly ash and its refractory properties, J. Mater. Sci. Lett. 19, 1263-1265 (2000).

4. Gonzalez-Velasco, J.R., Gutierrez-Ortiz, M.A. and Ferret, R., J. Mater. Sci. 34, 1999-2002 (1999). 
5. Tamborenea, S., Mazzoni, A.D. and Aglietti, E.F., Mechanochemical activation of minerals on the cordierite synthesis., Thermochim. Acta, 411, 224-219 (2003).

6. Yamuna, A., Johnson, R., Mahajan, Y.R. and Lalithambika, M., Kaolin-based cordierite for pollution control. J. Eur. Ceram. Soc. 24, 65-73 (2004).

7. Goren, R., Ozgur, C. and Gocmez. H., The preparation of cordierite from talc, fly ash, fused silica and alumina mixtures. Ceramics International, 32, 53-56 (2006).

8. Acimovic, Z., Pavlovic, L., Trumbulovic, L., Andric, L. and Stamatovic, M., Synthesis and characterization of the cordierite ceramics from nonstandard raw materials for application in foundry. Mater. Lett. 4217, 1-6 (2002).

9. Trumbulovic, L., Acimovic, Z., Panic, S. and Andric, L., Synthesis and characterization of cordierite from kaolin and talc for casting application. FME Trans. 31, 43-47 (2003).

10. Sumi, K., Kobayashi, Y. and Kato, E., Low-temperature fabrication of cordierite ceramics from kaolinite and magnesium hydroxide mixtures with boron oxide additions. J. Am. Ceram. Soc. 82 (3), 783-85 (1999).

11. Çakır, Ö., Production of cordierite from domestic raw materials. M. Sc. Thesis, Middle East Technical University, Ankara June (1981).

12. Kurama, S., Özel, E. and Ay, N. "Düşük Sicaklıkta Kordierite Üretime", 10 National Clay Symposium, Konya/TÜRKIYE, 524-531 (2001).

13. Tamborenea, S., Mazzoni, A.D. and Aglietti, E.F., Mechanochemical activation of minerals on the cordierite synthesis. Thermochimica Acta, 411, 219-224 (2004).

14. Levin, E. M., Robins, C. R. and MC Murdie, H.F., "Phase Diagrams for Ceramists" M. K. Rober, Ohio1(1985).

15. Kurama, S. and Ay, N., Effect of grinding time and $\mathrm{MgO}$ source on cordierite formation. Am. Ceram. Soc. Bul. 81 (11), 58-61 (2002).

16. ASTM Standards: C 373-88, Standard Test Method for Water Absorption, Bulk Density, Apparent Porosity and Apparent SpecificGravity of Fired Whiteware Products. pp.114-115 (1994). 
توصيف الكورديوريت المحضر من الكاولين المصرى والتلك محمد محمد عبد المنعم سليم (() ، صلاح الاين عبده حسن(ب) ، محمد رمضان عبدالسلام رزق (ع) ونصر الله محمد دراز (أود)

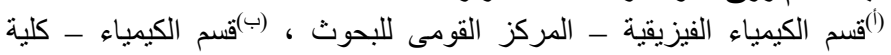

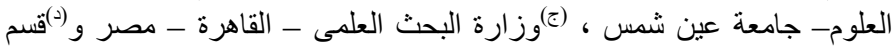

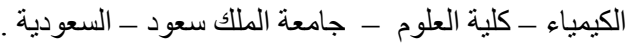

تم دراسة نحضير الكورديوريت من الكاولين المصري و التلاك و هيدروكسيد

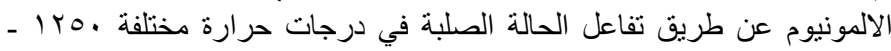

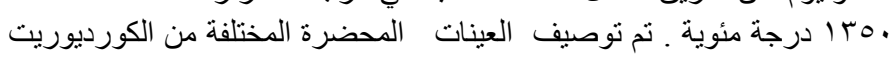

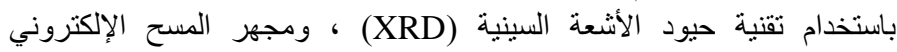

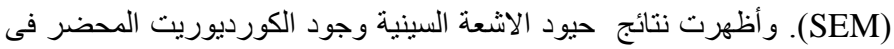

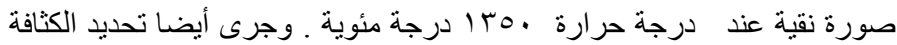
و المسامية للكورديوريت. 